\title{
Potent bioactivities of the endemic Annonaceae heighten its dire conservation status
}

\author{
Aruna Weerasinghe ${ }^{1}$, Shanmugam Puvenendran ${ }^{1}$, Anura Wickramasinghe ${ }^{1}$, D. Nedra Karunaratne ${ }^{1}$, \\ Siril Wijesundara ${ }^{2}$ and Veranja Karunaratne ${ }^{1^{*}}$ \\ ${ }^{I}$ Department of Chemistry, Faculty of Science, University of Peradeniya, Peradeniya. \\ ${ }^{2}$ Royal Botanic Gardens, Peradeniya.
}

\begin{abstract}
Sri Lanka records 17 endemic species of the Annonaceae family. Worldwide, the Annonaceae are known to possess compounds with pharmaceutically important properties such as anticancer and insecticidal actions. In an attempt to investigate the mosquito larvicidal and antioxidant activities of the endemic Annonaceae plants, twelve plant species were collected. Of the 71 extracts investigated from various plant parts, five plants showed significant larvicidal activity with the $\mathrm{CH}_{2} \mathrm{Cl}_{2}$ extracts of the leaves of $G$. hookeri and G. gardneri $\left(\mathrm{LC}_{50}\right.$ at $48 \mathrm{~h}=0.4$ and $0.3 \mathrm{ppm}$, respectively) exhibiting potency compared to the known larvicide (4S)-4methyl-2-(11-dodecynyl)-2-butenolide $\quad\left(\mathrm{LC}_{50}=0.3 \mathrm{ppm}\right)$. Compared to the percent radical scavenging activity of the standard dl- $\alpha$ tocopherol (55.84), the $\mathrm{MeOH}$ extracts of the stem of $A$. hortensis (56.30), the leaves of $U$. semecarpifolia (57.33), and the seeds of $X$. nigricans (62.06) showed very promising activity. Significantly, it is recorded that two of the Sri Lankan endemic Annonaceae plants are extinct (P. moonii and $A$. hortensis) and the rest, except for $U$. sphenocarpa, are critically endangered, endangered, vulnerable or near threatened. These grim statistics highlight not only the urgency and the importance of biodiversity conservation of the endemic Annonaceae of Sri Lanka but also of investigating the plants for new phamacophores.
\end{abstract}

Keywords: Annonaceae, antioxidant activity, biodiversity conservation, endemic species, mosquito larvicidal activity.

\section{INTRODUCTION}

In an estimated number of the 270,000 species of vascular flora, $12 \%$ are threatened (Walter \& Gillett, 1998) and these plants are scattered in 369 families found in 200 countries. Because of the lack of information due to, either poor taxonomic knowledge or gaps in field work, the number could be much higher. When the sample assessed is the population within a species, or when there is genetic erosion among species, the situation becomes grimmer (Harper \& Hawksworth, 1994; Gaston, 1996). In Sri Lanka, of the 3314 listed flowering plants, 455 are threatened with about 70 plants having become extinct by 1997 (Walter \& Gillett, 1998).

The World Conservation Monitoring Center has designated Sri Lanka as a 'hotspot' in terms of rich biodiversity and threats faced (Caldecott et al., 1994). About $25 \%$ of the flowering plant species are endemic to the island (Gunatilleke \& Gunatilleke, 1990). The relict rainforest plant taxa of Gondwana-Deccan ancestry are now found only in some isolated forest pockets in Penninsular India and Southwestern Sri Lanka. The Deccan flora evolved in isolation in the late Cretaceous and early Tertiary periods, during the drifting of the Indian plate (Jayasekara, 1997). It has been hypothesized that biotic impoverishment, prior absence followed by colonization and later speciation has led to the tremendous endemic diversity in the island (Biswas, 2008). Except for a few reports (Bandara et al., 1989; Hewage et al., 1997; Hewage et al., 1998), there has not been a large-scale systematic search for bioactive agents from Sri Lankan flora so far. Although endemic plants such as Salacia reticulata var. diandra (Celastraceae) have underscored the potential of Sri Lankan plants (Gunatilaka et al., 1993; Dhanabalasingham et al., 1996; Yoshikawa et al., 1997), in general the bioactivity potential of Sri Lankan endemics remains relatively unknown. As such, there is an urgent need to investigate their therapeutic potential before they disappear forever. 
The Annonaceae are woody trees, shrubs and vines comprising about 130 genera and 2,300 species worldwide. Considering its large size, it is chemically one of the least known of the tropical plant families (Leboeuf et al.,1982). However, plants of the Annonaceae have received increased phytochemical and pharmacological attention in recent years; this is mostly due to the discovery of Annonaceous acetogenins, a class of natural products with a variety of biological activities (Cave et al., 1997; Kojima \& Tanaka, 2009; Liaw et al., 2010). In Sri Lanka, Annonaceae is centered in the lowland rainforests (Dassanayake \& Fosberg, 1980). They extend to the dry and lower montane zones, but are absent from elevations above $1500 \mathrm{~m}$. Due to extensive deforestation in the humid regions, many species have become rare. In Sri Lanka, 17 endemic species, namely, Desmos zeylanica Hook. f. \& Thoms., Desmos elegans (Thwaites) Saff., Uvaria semecarpifolia Hook. f. \& Thoms., Uvaria sphenocarpa Hook. f. \& Thoms., Sageraea thwaitesii Hook. f. \& Thoms., Phoenicanthus coriacea (Thw.) H. Huber, Phoenicanthus obliqua (Hook. f. \& Thoms.) Alston, Alphonsea hortensis H. Huber, Polyalthia persicaefolia (Hook. f. \& Thoms.) Thw., Polyalthia moonii Thawaites, Miliusa zeylanica ex Hook. f. \& Thoms., Enicosanthum acuminata (Thw.) Airy-Shaw, Xylopia nigricans Hook. f. \& Thoms., Goniothalamus gardneri Hook. f. \& Thoms., Goniothalamus hookeri Thw., Goniothalamus thomsonii and Goniothalamus salicina Hook. f. \& Thoms., belonging to ten genera are recorded (Dassanayake \& Fosberg, 1980), although many have not been collected for decades. It is in this backdrop, that the antioxidant and mosquito larvicidal activities of the extracts of 12 Annonacea belonging to 8 genera are reported in the present investigation. However, five endemic Annonaceae species could not be collected during plant collection between 2004 to 2010, which may have disappeared from their known habitats.

\section{METHODS AND MATERIALS}

Endemic Annonaceae plants were collected from Central Sri Lanka during 2004 - 2010 (Table 1) and identified and deposited at the National Herbarium of Royal Botanic Gardens, Peradeniya.

Air dried, ground plant materials (100 - 500 g) were extracted sequentially for $24 \mathrm{~h}$ at room temperature with $\mathrm{CH}_{2} \mathrm{Cl}_{2}$ followed by $\mathrm{MeOH}$ (500 - $1500 \mathrm{~mL}$ each) by using a bottle shaker. The combined extracts were concentrated in vacuo at $35{ }^{\circ} \mathrm{C}$ to obtain the respective crude extracts.
The mosquito larvicidal assay was carried out according to Ratnayake et al. (2001), with solutions of $0.5 \mathrm{mg} / \mathrm{mL}$ (500 ppm) of the plant extracts using second instar larvae of Aedes aegypti. The potent larvicide, (4S)-4-methyl-2-(11-dodecynyl)-2-butenolide was used as the postive control (Ratnayake et al., 2001). $\mathrm{LC}_{50}$ values at $48 \mathrm{~h}$ (mean $\pm \mathrm{SD}$ ) in ppm, were based on 4 concentrations and 4 replicates and were determined by using MiniTab statistical software.

Radical scavenging activity (antioxidant activity) of plant extracts against stable DPPH radicals was determined spectrophotometrically by the slightly modified methods of Miliauskas et al. (2004) and Yen and Duh (1994). dl- $\alpha$ tocopherol was used as the positive control. All the determinations were performed in 3 replicates and averaged.

\section{RESULTS AND DISCUSSION}

Out of the 71 extracts studied, 25 extracts showed toxicity against $A$. aegypti. The extracts of G. gardneri and $G$. hookeri demonstrated exceptionally high larvicidal activity while A. hortensis, E. acuminata, $X$. championii, U. sphenocarpa and U. semecarpifolia showed significant activity (Table 1). The most active was the dichloromethane leaf extracts of $G$. hookeri and $G$. gardneri $\left(\mathrm{LC}_{50}\right.$ at $48 \mathrm{~h}=0.4$ and $0.3 \mathrm{ppm}$, respectively). Significantly, larvicidal potency of extracts of $G$. hookeri and G. gardneri were comparable with the potent larvicide (4S)-4-methyl-2-(11-dodecynyl)-2butenolide (Ratnayake et al., 2001). Although no reports of either bioactivity or use in traditional medicine exists for these two plants in Sri Lanka, plants of the genus Goniothalamus are known for the presence of cytotoxic acetogenins and styryl-lactones (Leboeuf et al.,1982). However, of the large majority of the 166 Goniothalamus plants known globally, only 22 species have so far been investigated (Wiart, 2007).

Several extracts exhibited potent percent antioxidant activity. For example, $\mathrm{MeOH}$ extract of the stem of A. hortensis (56.30), the leaves of U. semecarpifolia (57.33), and the seeds of $X$. nigricans (62.06) showed higher radical scavenging activity compared to the standard $\mathrm{dl}$ - $\alpha$-tocopherol (55.84). In recent times, free radicals have been implicated in inflammation processes, cardiovascular disease, rheumatoid arthritis, neurodegenerative disease, and the ageing process (Hollman \& Katan, 1999). X. nigricans, X. parvifolia and $X$. championii, of which the latter two are non-endemic, are rich in isoquinoline alkaloids where some have shown potent antioxidant activity (Wijeratne et al., 1996, 2001; Puvenendran et al., 2008, 2010). 
Table 1: Mosquito larvicidal activity and antioxidant activity of endemic Annonaceae of Sri Lanka

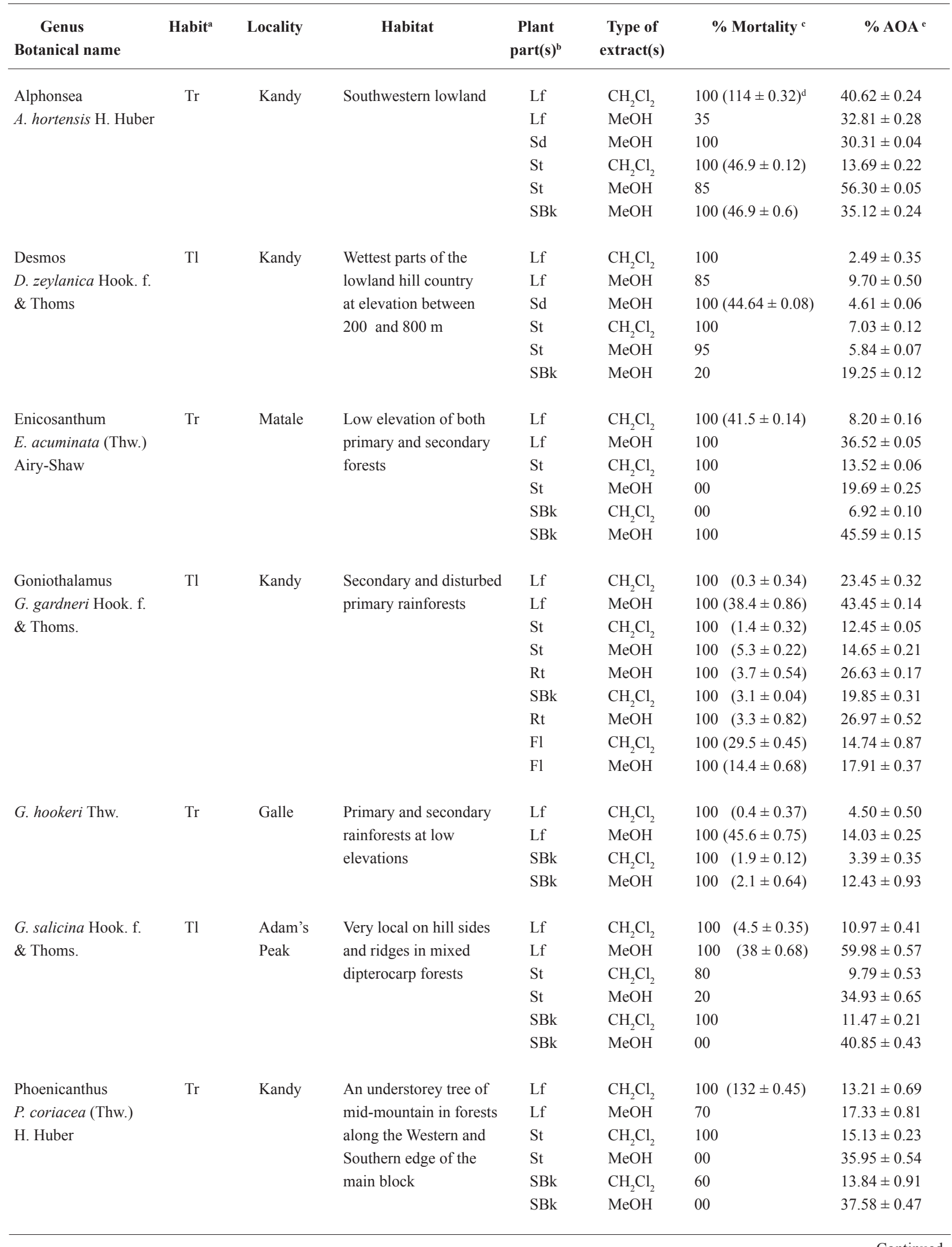


- Continued from page 347 -

\begin{tabular}{|c|c|c|c|c|c|c|c|}
\hline $\begin{array}{c}\text { Genus } \\
\text { Botanical name }\end{array}$ & Habit $^{\mathrm{a}}$ & Locality & Habitat & $\begin{array}{c}\text { Plant } \\
\operatorname{part}(\mathbf{s})^{\mathrm{b}}\end{array}$ & $\begin{array}{c}\text { Type of } \\
\operatorname{extract}(s)\end{array}$ & $\%$ Mortality $^{\mathrm{c}}$ & $\% \mathrm{AOA}^{\mathrm{e}}$ \\
\hline \multirow{4}{*}{$\begin{array}{l}\text { P. obliqua } \\
\text { Hook. f. \& Thoms. }\end{array}$} & \multirow[t]{4}{*}{$\operatorname{Tr}$} & \multirow[t]{4}{*}{ Kandy } & \multirow{4}{*}{$\begin{array}{l}\text { A tree in the } \\
\text { South west of } \\
\text { Sri Lanka }\end{array}$} & $\mathrm{Lf}$ & $\mathrm{CH}_{2} \mathrm{Cl}_{2}$ & 80 & $11.24 \pm 0.78$ \\
\hline & & & & Lf & $\mathrm{MeOH}$ & 00 & $20.98 \pm 0.65$ \\
\hline & & & & St & $\mathrm{CH}_{2} \mathrm{Cl}_{2}$ & 100 & $14.56 \pm 0.37$ \\
\hline & & & & St & $\mathrm{MeOH}$ & 20 & $27.90 \pm 0.54$ \\
\hline \multirow{4}{*}{$\begin{array}{l}\text { Sageraea } \\
\text { Sageraea thwaitesii } \\
\text { Hook. f. \& Thoms. }\end{array}$} & \multirow[t]{4}{*}{$\operatorname{Tr}$} & Nuwara & \multirow{4}{*}{$\begin{array}{l}\text { A tree found in the } \\
\text { entire country }\end{array}$} & Lf & $\mathrm{CH}_{2} \mathrm{Cl}_{2}$ & 70 & $10.87 \pm 0.65$ \\
\hline & & Eliya & & Lf & $\mathrm{MeOH}$ & 20 & $40.64 \pm 0.82$ \\
\hline & & & & St & $\mathrm{CH}_{2} \mathrm{Cl}_{2}$ & 80 & $32.96 \pm 0.32$ \\
\hline & & & & St & $\mathrm{MeOH}$ & 40 & $16.63 \pm 0.43$ \\
\hline \multirow{6}{*}{$\begin{array}{l}\text { Uvaria } \\
\text { U. sphenocarpa } \\
\text { Hook. f. \& Thoms. }\end{array}$} & \multirow[t]{6}{*}{$\mathrm{Cl}$} & \multirow[t]{6}{*}{ Kandy } & \multirow{6}{*}{$\begin{array}{l}\text { Local in both dry and } \\
\text { wet parts of the island } \\
\text { at elevations between } \\
\text { sea level and } 720 \mathrm{~m}\end{array}$} & Lf & $\mathrm{CH}_{2} \mathrm{Cl}_{2}$ & 70 & $6.08 \pm 0.20$ \\
\hline & & & & Lf & $\mathrm{MeOH}$ & 00 & $1.49 \pm 0.06$ \\
\hline & & & & St & $\mathrm{CH}_{2} \mathrm{Cl}_{2}$ & 00 & $4.24 \pm 0.10$ \\
\hline & & & & St & $\mathrm{MeOH}$ & 00 & $42.93 \pm 0.80$ \\
\hline & & & & SBk & $\mathrm{CH}_{2} \mathrm{Cl}_{2}$ & 70 & $3.52 \pm 0.23$ \\
\hline & & & & SBk & $\mathrm{MeOH}$ & 00 & $23.66 \pm 0.17$ \\
\hline \multirow{5}{*}{$\begin{array}{l}\text { U. semecarpifolia } \\
\text { Hook. f. \& Thoms. }\end{array}$} & \multirow[t]{5}{*}{$\mathrm{Cl}$} & \multirow[t]{5}{*}{ Kegalle } & \multirow{5}{*}{$\begin{array}{l}\text { Rather uncommon both } \\
\text { in primary rainforests } \\
\text { and secondary regrowth } \\
\text { at elevations between } \\
70 \text { to } 600 \mathrm{~m}\end{array}$} & Lf & $\mathrm{CH}_{2} \mathrm{Cl}_{2}$ & 00 & $19.31 \pm 0.20$ \\
\hline & & & & Lf & $\mathrm{MeOH}$ & 00 & $57.33 \pm 0.42$ \\
\hline & & & & SBk & $\mathrm{CH}_{2} \mathrm{Cl}_{2}$ & 65 & $33.23 \pm 0.12$ \\
\hline & & & & SBk & $\mathrm{MeOH}$ & 00 & $26.66 \pm 0.60$ \\
\hline & & & & & & & \\
\hline \multirow{6}{*}{$\begin{array}{l}X . \text { nigricans } \\
\text { Hook. f. \& Thoms. }\end{array}$} & \multirow[t]{6}{*}{$\operatorname{Tr}$} & \multirow[t]{6}{*}{ Matale } & \multirow{6}{*}{$\begin{array}{l}\text { Rare tree of the dry and } \\
\text { intermediate zones at low } \\
\text { elevations }\end{array}$} & Lf & $\mathrm{CH}_{2} \mathrm{Cl}_{2}$ & 45 & $21.03 \pm 0.39$ \\
\hline & & & & Lf & $\mathrm{MeOH}$ & 00 & $33.92 \pm 0.40$ \\
\hline & & & & $\mathrm{Sd}$ & $\mathrm{CH}_{2} \mathrm{Cl}_{2}$ & 50 & $14.33 \pm 0.67$ \\
\hline & & & & $\mathrm{Sd}$ & $\mathrm{MeOH}$ & 00 & $62.06 \pm 0.33$ \\
\hline & & & & $\mathrm{St}+\mathrm{SBk}$ & $\mathrm{MeOH}$ & $100(142.5 \pm 0.81)$ & $25.58 \pm 0.43$ \\
\hline & & & & $\mathrm{St}+\mathrm{SBk}$ & $\mathrm{CH}_{2} \mathrm{Cl}_{2}$ & 00 & $9.18 \pm 0.32$ \\
\hline \multirow{4}{*}{$\begin{array}{l}\text { X. championii } \\
\text { Hook. f. \& Thoms. }\end{array}$} & \multirow[t]{4}{*}{$\operatorname{Tr}$} & \multirow[t]{4}{*}{ Kithulgala } & \multirow{4}{*}{$\begin{array}{l}\text { Wet parts of the country } \\
\text { in the intermediate zones }\end{array}$} & Lf & $\mathrm{CH}_{2} \mathrm{Cl}_{2}$ & 65 & $27.82 \pm 0.35$ \\
\hline & & & & Lf & $\mathrm{MeOH}$ & 55 & $48.45 \pm 0.19$ \\
\hline & & & & $\mathrm{S}+\mathrm{SBk}$ & $\mathrm{CH}_{2} \mathrm{Cl}_{2}$ & $100(137.5 \pm 0.75)$ & $26.28 \pm 0.04$ \\
\hline & & & & $\mathrm{S}+\mathrm{SBk}$ & $\mathrm{MeOH}$ & $100(104.0 \pm 0.42)$ & $25.18 \pm 0.6$ \\
\hline
\end{tabular}

a Tr, Tree; Tl, Treelet; Cl, Climber. ${ }^{\text {b }}$ Lf, Leaf; Sd, Seed; St, Stem; SBk, Stembark; Rt, Root; Fl, Flower.

c Average of four replicates, each beaker containing five second instar larvae of $\mathrm{A}$. aegypti; \% Mortality at $48 \mathrm{~h}$ with $500 \mathrm{ppm}$ solution of extract; Solutions with no extract was used as a negative control; (4S)-4-methyl-2-(11-dodecynyl)-2-butenolide, which gives $100 \%$ mortality at 1 ppm was used as positive control.

d $\mathrm{LC}_{50}$ values stated as Mean $\pm \mathrm{SD}$, in ppm, were based on four concentrations and four replicates.

e Percentage antioxidant activity (AOA) is based on three replications and is stated as Mean \pm SD. The absorbance of the DPPH radical without antioxidant (negaive control) and the reference compound $D L$ - $\alpha$-tocopherol (positive control) which exhibited activity at $55.84 \pm 0.05$ were also measured.

A species is considered nationally threatened when it is evaluated to be critically endangered (CR), endangered (EN), or vulnerable (V) (Walter \& Gillett, 1998). Globally, it is estimated that $9.2 \%$ of Annonaceae species are threatened (Walter \& Gillett, 1998). In 1997, among the
Sri Lankan Annonaceae, P. perscicaefolia, P. moonii, A. hortensis, G. thomsonii, M. zeylanica, P. coriacea, $P$. obliqua, $U$. semecarpifolia and $X$. nigricans, were considered indeterminate (Table 2), while $G$. hookeri, S. thwaitesii and E. acuminata were considered vulnerable. On the other hand, D. elegans, 
Table 2: Endemic Annonaceae conservation status in 1997

\begin{tabular}{lll}
\hline Inditerminate & Vulnerable & Not threatened \\
\hline P. perscicaefolia & G. hookeri & D. elegans \\
P. moonai & S. thwaitesii & D. zeylanica \\
A. hortensis & E. acuminata & G. gardneri \\
G. thomsonii & & G. salicina \\
M. zeylanica & & U. sphenocarpa \\
P. coriacea & \\
P. obliqua & \\
U. semecarpifolia & \\
X. nigricans & \\
\hline
\end{tabular}

Source : Walter and Gillett, 1998 its very promising potential as a source of plant medicines. However, it also highlights the grim conservation status of the endemic Annonaceae. If urgent remedial action is not undertaken towards their conservation, these plants will be well on their way towards extinction. This work also highlights the importance of screening the endemic flora of the South Asian region for potential drugs before they are threatened by deforestration and other anthropogenic factors.

\section{Acknowledgement}

Authors thank the National Science Foundation and the National Research Council, Sri Lanka for research funding.

Table 3: Endemic Annonaceae conservation status in 2010

\begin{tabular}{llllll}
\hline \multicolumn{1}{c}{ EX } & \multicolumn{1}{c}{ CR } & \multicolumn{1}{c}{ EN } & \multicolumn{1}{c}{ V } & \multicolumn{1}{c}{ NT } & \multicolumn{1}{c}{ LC } \\
\hline \multirow{2}{*}{ A. hortensis } & P. perscicaefolia & G. salicina & D. zeylanica & D. elegans & U. sphenocarpa \\
P. moonai & & M. zeylanica & G. gardneri & X. nigricans & \\
& & P. coriacea & G. hookeri & U. semecarpifolia & \\
& & G. thomsonii & P. obliqua & \\
& & & S. thwaitesii \\
& & & & \\
& & & & \\
& & & & \\
& &
\end{tabular}

Source : Weerakoon \& Wijesundara, 2012.

EX (Extinct); CE (Critically Endangered); E (Endangered); V (Vulnerable); NT (Near Threatened); LC (Least Concerned)

D. zeylanica, G. gardneri, G. salicina and U. sphenocarpa were considered not threatened. However, by 2011 (Weerakoon \& Wijesundara, 2012), the situation had dramatically shifted (Table 3) with $P$. moonii being extinct and $A$. hortensis having become extinct in the wild; P. perscicaefolia becoming critically endangered; $G$. salicina, M. zeylanica and $P$. coriacea considered endangered; D. zeylanica, E. acuminata, G. gardneri, $G$. hookeri, G. thomsonii and S. thwaitesii being vulnerable; D. elegans, $X$. nigricans, $U$. semecarpifolia and $P$. obliqua becoming near threatened. The only species apparently out of danger is $U$. sphenocarpa. Thus, the majority of the 17 endemic Annonaceae species are nationally threatened and one is extinct. This dire situation far exceeds the global average $(9.2 \%)$ of threatened species calling attention to a crisis situation. During the collection attempts, D. elegans, $P$. perscicaefolia, $G$. thomsonii, P. moonii and M. zeylanica could not be located due to their disappearance from recorded sites.

In conclusion, this study reveals the richness of bioactivity of the endemic Annonaceae of Sri Lanka, and

\section{REFERENCES}

1. Bandara B.M.R.B., Fernando I.H.S., Hewage C.M., Karunaratne V., Adikaram N.K.B. \& Wijesundara D.S.A. (1989). Antifungal activity of some medicinal plants of Sri Lanka. Journal of the National Science Council of Sri Lanka 17(1): 1 - 13.

2. Biswas S. (2008). Did biotic impoverishment facilitate phenomenal diversification in Sri Lanka. Current Science 95(8): $1021-1025$.

3. Caldecott J.O., Jenkins M.D., Johnson T. \& Groombridge B. (1994). Priorities for conserving global species richness and endemism. World Conservation Monitoring Center, Biodiversity Series No. 3 (ed. N.M. Collins), pp. 17. World Conservation Press, Cambridge, UK.

4. Cave A., Figadère B., Laurens A. \& Cortes D. (1997). Acetogenins from Annonaceae. Progress in the Chemistry of Organic Natural Products (eds. W. Hertz, G.W. Kirby, R.E. Moore, W. Steglish \& C. Tamm), pp. $81-287$. Springer-Verlag, New York, USA.

5. Dassanayake M.D. \& Fosberg F.R. (1980 - 1987). A Revised Handbook to the flora of Ceylon. Amerind Publishers, New Delhi, India. 
6. Dhanabalasingham B., Karunaratne V., Gunatilaka A.A.L., Tezuka Y. \& Kikuchi T. (1996). Biogenetically important quinonemethides and other constituents of Salacia reticulata. Phytochemistry 42: 1377.

7. Gaston K.J. (ed.) (1996). What is Biodiversity? Biodiversity: A Biology of Numbers and Difference, pp. 1 - 9. Blackwell Science Ltd., Oxford, UK.

8. Gunatilleke I.A.U.N. \& Gunatilleke C.V.S. (1990). Distribution of floristic richness and its conservation in Sri Lanka. Conservation Biology 4(1): 21 - 31 . DOI:http://dx.doi.org/10.1111/j.1523-1739.1990.tb00262.x

9. Gunatilaka A.A.L., Dhanabalasingham B., Karunaratne V., Kikuchi T. \& Tezuka Y. (1993). Studies on terpenoids and steroids. part 27. structure of a D:AFriedo oleanane triterpenoid from Salacia reticulate and revision of the structure of Kokoonol, Kokzeylanol series of triterpenoids. Tetrahedron 45: 10397 - 10404.

10. Harper J.L. \& Hawksworth D.L. (1994). Biodiversity: measurement and estimation. Philosophical Transactions of the Royal Society B 345: 5-12.

DOI: http://dx.doi.org/10.1098/rstb.1994.0081

11. Hewage C.M., Bandara K.A.N.P., Karunaratne V., Bandara B.M.R. \& Wijesundara D.S.A. (1997). Insecticidal activity of some medicinal plants of Sri Lanka. Journal of the National Science Council of Sri Lanka 25(3): 141 - 150.

DOI: http://dx.doi.org/10.4038/jnsfsr.v26i1.3082

12. Hewage C.M., Bandara B.M.R.B., Karunaratne V., Wannigama G.P., Pinto M.R.M. \& Wijesundara D.S.A. (1998). Antibacterial activity of some medicinal plants of Sri Lanka. Journal of the National Science Council of Sri Lanka 26(1): 27 - 34.

13. Hollman P.C. \& Katan M.B. (1999). Health effects and bioavailability of dietary flavonols. Free Radical Research 31: $75-80$. DOI: http://dx.doi.org/10.1080/10715769900301351

14. Jayasekara R. (1997). Flora. Arjuna's Atlas of Sri Lanka (eds. T. Somesekaram, M.M.P. Perera, M.B.G De Silva \& H. Godellawatta), pp. 36 - 38. Arjuna Consulting Company Limited, Dehiwala.

15. Kojima N. \& Tanaka T. (2009). Medicinal chemistry of Annonaceous acetogenins: design, synthesis, and biological evaluation of novel analogues. Molecules 14(9): 3621 - 3661.

DOI: http://dx.doi.org/10.3390/molecules 14093621

16. Leboeuf M., Cavè A., Bhaunik P.K. \& Mukherjee B. (1982). The phytochemistry of the Annonaceae. Phytochemistry 21: $2783-2813$.

17. Liaw C.C., Wu T.Y., Chang F.R. \& Wu Y.C. (2010). Historic perspectives on Annonaceous acetogenins from the chemical bench to preclinical trials. Planta Medica 76(13): $1390-1404$.

DOI: http://dx.doi.org/10.1055/s-0030-1250006
18. Miliauskas G., Venskutonis P.R. \& Beek T.A.V. (2004). Screening of radical scavenging activity of some medicinal and aromatic plant extracts. Food Chemistry 85: $231-237$.

DOI: http://dx.doi.org/10.1016/j.foodchem.2003.05.007

19. Puvanendran S., Carr G., Wickramasinghe A., Karunaratne D.N., Wijesundara D.S.A., Andersen R.J. \& Karunaratne V. (2008). Antioxidant constituents of Xylopia championii. Pharmaceutical Biology 46: 252 - 256.

DOI: http://dx.doi.org/10.1080/13880200801887989

20. Puvanendran S., Manoranjan T., Wickramasinghe A., Karunaratne D.N., Kumar V., Wijesundara D.S.A., Carr G., Andersen R.J. \& Karunaratne V. (2010). Alkaloids from Xylopia parvifolia and Xylopia nigricans (Annonaceae). Journal of the National Science Foundation of Sri Lanka 38: 75 - 76.

21. Ratnayake R., Karunaratne V., Ratnayake B.M.R., Kumar V., MacLeod J.K. \& Simmonds P. (2001). Two new lactones with mosquito larvicidal activity from three Hortonia species. Journal of Natural Products 64: 376 - 378.

DOI: http://dx.doi.org/10.1021/np000371t

22. Walter K.S. \& Gillett H.J. (eds). (1998). 1997 IUCN Red List of Threatened Plants, pp. 862. World Conservation Union, Gland, Switzerland and Cambridge, UK.

23. Wiart C. (2007). Goniothalamus species: A source of drugs for the treatment of cancers and bacterial infections? Evidence-Based Complimentary and Alternative Medicine 4(3): 299 - 311.

DOI: http://dx.doi.org/10.1093/ecam/nem009

24. Wijeratne E.M.K., Hatanaka Y., Kikuchi T., Tezuka Y., \& Gunatilaka A.A.L. (1996). A dioxoaporphine and other alkaloids of two annonaceous plants of Sri Lanka. Phytochemistry 42(6): 1703 - 1706.

25. Wijeratne E.M., Lankananda B.D., Tezuka Y., Nagaoka T. \& Gunatilaka A.A.L. (2001). Dimeric aporphine alkaloids of Phoenicanthus obliqua from Sri Lanka. Phytochemistry 64: $1465-1467$.

26. Weerakoon D. \& Wijesundara S. (eds.) (2012). The National Red List 2012 of Sri Lanka, Conservation Status of Flora and Fauna, pp. 217 - 218. Ministry of Environment, Colombo.

27. Yen G.C. \& Duh P.D. (1994). Scavenging effect of methanolic extracts of peanut hulls on free radical and active-oxygen species. Journal of Agriculture and Food Chemistry 42: $629-632$.

DOI: http://dx.doi.org/10.1021/jf00039a005

28. Yoshikawa M., Murakami T., Shimada H., Matsuda H., Yamahara J., Tanabe G. \& Muraoka O. (1997). Salacinol, potent antidiabetic principle with unique thiosugar sulfonium sulfate structure from the ayurvedic traditional medicine Salacia reticulata in Sri Lanka and India. Tetrahedron Letters 4: 8367 - 8370. 